\title{
Two New Cholestanol Glycosides from the Roots and Rhizomes
}

\author{
of Smilacina henryi \\ Xin Zhang 1, 2, \#, Jing Sun 2, \#,*, Shuo Zhang ${ }^{3}$, Yafeng Yan ${ }^{2}$, \\ Rongxin Zhang ${ }^{2}$, Xuanji Xue ${ }^{1,4}$ and Zengjun Guo ${ }^{1,4 *}$ \\ ${ }^{1}$ School of Pharmacy, Xi'an Jiaotong Univeristy, Xi'an 710061, China \\ ${ }^{2}$ School of Pharmacy, Shaanxi University of Chinese Medicine, Xianyang 712046, China \\ ${ }^{3}$ School of Traditional Chinese Medicine, Beijing University of Chinese Medicine, Beijing, China \\ ${ }^{4}$ Shaanxi key laboratory of "Qiyao" resources and anti-tumor acitivities, Xi'an 710061, China
}

(Received April 15, 2019; Revised May 07, 2019; Accepted May 08, 2019)

\begin{abstract}
Two new cholestanol glycosides (1 and 2) were obtained from the roots and rhizomes of Smilacina henryi. Their structures were determined as $5 \alpha$-cholest-9(11)-ene-3 $\beta$, 26-dihydroxy-16, 22-dione 3-O- $\beta$-D-glucopyranosyl-( $(1 \rightarrow 2)-\beta$-D-galactopyranoside $\quad(\mathbf{1}), \quad 5 \alpha$-cholest-9(11)-ene-3 $\beta, \quad 26$-dihydroxy-16, 22-dione $\quad 3$ - $O-\beta$-D-glucopyranosyl-( $1 \rightarrow 2)$-[ $\beta$-D-glucopyranosyl-( $1 \rightarrow 3)]-\beta$-D-galactopyranoside $\quad(2), \quad$ by physicochemical properties and spectroscopic methods. In addition, the isolated glycosides were tested for their cytotoxic activity against human HepG2 tumor cells and compound 2 showed moderate activity with $\mathrm{IC}_{50}$ value of $59.32 \mu \mathrm{M}$.
\end{abstract}

Keywords: Smilacina henryi; cholestanol glycosides; structure determination; cytotoxicity. (C) 2019 ACG Publications. All rights reserved.

\section{Introduction}

Smilacina henryi (bekev) Wang et Tang, mainly distributed in Asia, Europe and north America, is a prennial herb in the genus Smilacina (Liliaceae) [1,2]. As one of about 16 species grown in china, S. henryi is widely distributed in Shaanxi, Hebei, and Yunnan province. Its roots, named Pian Tou Qi in the region of Qinba Mountains of Shaanxi province, are usually used as traditional Chinese medicines (TCMs) for the treatment of rheumatism, traumatic injury and impotence [3-7]. Some chemical constituents have been isolated from $S$. henryi such as steroidal saponins and flavoids [3, 8]. In our research project of searching for the bioactive constituents from TCMs [9, 10], an investigation

\footnotetext{
\# These authors contribute equally to this paper

*Corresponding authors: E- Mail: guozj@ mail.xjtu.edu.cn (Prof. Guo); ph.175@163. com (Prof. Sun);

Phone: +86(029)82655133 (Prof. Guo); +86(029)38184958 (Prof. Sun).

The article was published by ACG Publications

http://www.acgpubs.org/journal/records-of-natural-products November-December 2019 EISSN:1307-6167

DOI: http://doi.org/10.25135/rnp.19.03.1248
} 
Two new cholestanol glycosides

of secondary metabolites of $S$. henryi was carried out and two new cholestanol glycosides were obtained. Additionally, their cytotoxic activities against human HepG2 tumor cells were also studied. The isolation, structural elucidation and cytotoxic evaluation for the glycosides were reported in this paper.

\section{Materials and Methods}

\subsection{General Experimental Procedures}

Optical rotation was measured using a Rudolph Autopol VI polarimeter (Rudolph, USA); IR spectra were recorded on a Nicolet iS10 instrument (Thermo Fisher Scientific, USA); 1D and 2D NMR spectra were recorded on a Bruker-Avance 400 instrument (Bruker Corp. Karlsruhe, Germany); Semipreparative HPLC was performed on Agilent infinity II system equipped with a UV detector and a YMC-Pack-ODS-A $(10 \mathrm{~mm} \times 250 \mathrm{~mm}, 5 \mu \mathrm{m}$ particles $)$ column. The HR-ESI-MS spectra were taken on an Agilent Technologies 6650 Q-TOF (Agilent Technologies). Sephadex LH-20 gel and ODS $C_{18}$ $(5 \mu \mathrm{m})$ silica gel was purchased from GE Healthcare Bio-Sciences AB (Uppsala, Sweden). Silica gel was purchased from Qingdao Haiyang Chemical Group Corporation (Qingdao, China).

\subsection{Plant Material}

The roots and rhizomes of Smilacina henryi (bekev) Wang et Tang were collected on August in 2017 from Qinba Mountains in Shaanxi Province of China, and were authenticated by one of our co-authors Prof. Jing Sun (Shaanxi University of Chinese Medicine). A voucher specimen (herbarium No. SH-201708) is deposited in School of Pharmacy, Xi'an Jiaotong University, Xi'an 710061, China.

\subsection{Extraction and Isolation}

The air-dried roots and rhizomes of $S$. henryi $(6.6 \mathrm{~kg})$ were extracted with $80 \%$ EtOH under reflux for three times $(2 \mathrm{~h}, 2 \mathrm{~h}, 1 \mathrm{~h}$, successively). The concentrated residue was partitioned with petroleum ether (PE) and $n-\mathrm{BuOH}$ successively. The $n-\mathrm{BuOH}$ extract $(130.2 \mathrm{~g})$ was subjected to column chromatography (CC) on silica gel (1 kg), eluting with gradient solvent system $\left(\mathrm{CH}_{2} \mathrm{Cl}_{2}-\mathrm{MeOH}-\mathrm{H}_{2} \mathrm{O}, 100: 0: 0-60: 40: 10\right)$ to give six fractions (Fr.1 - Fr.6). Fr.4 (19.1 g) was subjected to CC on silica gel (200 g), eluting with $\left(\mathrm{CH}_{2} \mathrm{Cl}_{2}-\mathrm{MeOH}-\mathrm{H}_{2} \mathrm{O}, 100: 10: 0-80: 20: 5\right)$ to give six subfractions (Fr.4-1 - Fr.4-6). Fr.4-3 (3.1 g) subjected to CC on Sephadex LH-20 gel (100 g) eluting with $\left(\mathrm{CH}_{2} \mathrm{Cl}_{2}-\mathrm{MeOH}\right.$ 100:100) to give ten subfractions (Fr.4-3-1 - Fr.4-3-10). Fr.4-3-2 (55.7 $\mathrm{mg}$ ) was purified by HPLC (YMC-Pack-ODS-A, $10 \mathrm{~mm} \times 250 \mathrm{~mm}, 5 \mu \mathrm{m}$ particles, flow rate: 1.5 $\mathrm{mL} / \mathrm{min}$ ) with $\mathrm{MeCN}-\mathrm{H}_{2} \mathrm{O}$ (70:30) as mobile phase to afford compound $2\left(16.9 \mathrm{mg} ; t_{R}=19.7 \mathrm{~min}\right)$, Fr.4-3-4 (31.1 mg) was purified by HPLC (YMC-Pack-ODS-A, $10 \mathrm{~mm} \times 250 \mathrm{~mm}, 5 \mu \mathrm{m}$ particles, flow rate: $1.5 \mathrm{~mL} / \mathrm{min}$ ) with $\mathrm{MeCN}-\mathrm{H}_{2} \mathrm{O}$ (72:28) as mobile phase to afford compound $\mathbf{1}$ (10.4 $\mathrm{mg} ; t_{R}$ $=28.4 \mathrm{~min})$. 


\subsection{Spectroscopic Data}

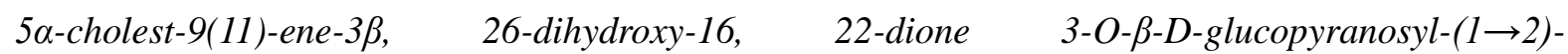
$\beta$-D-galactopyranoside (1): A white amorphous powder; $[\alpha]_{D}^{20}-49.4^{\circ}(c 0.18, \mathrm{MeOH})$; IR $(\mathrm{KBr}) v_{\max }$ : $3419,2926,1736,1614,1455,1067,890,770 \mathrm{~cm}^{-1} ; \mathrm{m} / \mathrm{z} 777.4025[\mathrm{M}+\mathrm{Na}]^{+}($calcd for 777.4037 $\left.\mathrm{C}_{39} \mathrm{H}_{62} \mathrm{O}_{14} \mathrm{Na}^{+}\right) .{ }^{1} \mathrm{H}-\mathrm{NMR}$ and ${ }^{13} \mathrm{C}-\mathrm{NMR}$ data $\left(400 \mathrm{MHz}\right.$ and $100 \mathrm{MHz}$ in pyridine- $d_{5}$ ) see Table 1.

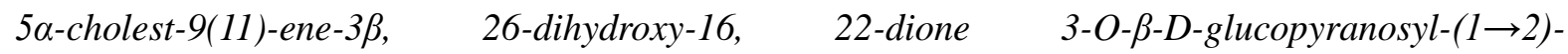
$[\beta$-D-glucopyranosyl- $(1 \rightarrow 3)]-\beta$-D-galactopyranoside $(2):$ A white amorphous powder; $[\alpha]_{D}^{20}-20.0^{\circ}(c$ $0.1, \mathrm{MeOH})$; IR (KBr) $v_{\max }: 3417,2926,1736,1704,1603,1456,1068,688 \mathrm{~cm}^{-1} ; \mathrm{m} / z 939.4532[\mathrm{M}+$ $\mathrm{Na}]^{+}$(calcd for $939.4565 \mathrm{C}_{45} \mathrm{H}_{72} \mathrm{O}_{19} \mathrm{Na}^{+}$). ${ }^{1} \mathrm{H}-\mathrm{NMR}$ and ${ }^{13} \mathrm{C}-\mathrm{NMR}$ data $(400 \mathrm{MHz}$ and $100 \mathrm{MHz}$ in pyridine- $d_{5}$ ) see Table 1 .

\subsection{Acid Hydrolysis}

Solutions of $\mathbf{1}$ and 2 (5 mg each) were hydrolyzed in $2 \mathrm{M}$ hydrochloric acid $(5 \mathrm{~mL})$ at $80{ }^{\circ} \mathrm{C}$ for $2 \mathrm{~h}$. After cooling, each solution was concentrated under vacuum, dissolved with water, and extracted twice with dichloromethane $\left(\mathrm{CH}_{2} \mathrm{Cl}_{2}\right)$. The aqueous parts were subjected to $\mathrm{CC}$ on ODS $\mathrm{C}_{18}$ silica gel (10 g), eluting with $\left(\mathrm{MeCN}-\mathrm{H}_{2} \mathrm{O}, 5: 95\right)$ to give two products. The D configurations of the galactose and the glucose moieties in $\mathbf{1}$ and $\mathbf{2}$ were confirmed through their optical rotation data (Gal: $[\alpha]_{D}^{20}+29.0^{\circ}, \mathrm{MeOH}$ and Glc: $\left.[\alpha]_{D}^{20}+48.8^{\circ}, \mathrm{MeOH}\right)$ and $R_{f}$ values $\left(\mathrm{BuOH}-\mathrm{AcOH}-\mathrm{H}_{2} \mathrm{O}, 4: 1: 5\right.$ upper layer, Gal: 0.39 and Glc: 0.36 ) with the authentic sugar samples [11].

\subsection{Cytotoxic Activity Assay}

The cytotoxic activity assay toward the human HepG2 cell lines was measured by the MTT method (positive control: 5-fluorouracil, $\mathrm{IC}_{50} 12.07 \mu \mathrm{M}$ ). Briefly, $1 \times 10^{4} / \mathrm{mL}$ cells were seeded into 96-well plates and allowed to adhere for $24 \mathrm{~h}$. Compounds 1 and 2 were dissolved in DMSO and diluted with complete medium to 6 degrees of concentration for inhibition rate determination. After incubation at $37.8^{\circ} \mathrm{C}$ for $4 \mathrm{~h}$, the supernatant was removed before adding DMSO $(100 \mu \mathrm{L})$ to each well [8].

\section{Results and Discussion}

Compound 1, white amorphous powder, with $[\alpha]_{D}^{20}-49.4^{\circ}(c 0.18, \mathrm{MeOH})$, has a molecular formula of $\mathrm{C}_{39} \mathrm{H}_{62} \mathrm{O}_{14}$ which was deduced from the HR-ESI-MS positive molecular ion peak at $\mathrm{m} / \mathrm{z}$ $777.4025[\mathrm{M}+\mathrm{Na}]^{+}\left(\right.$calcd for $\left.777.4037[\mathrm{M}+\mathrm{Na}]^{+}\right)$. Four steroid methyl groups at $\delta_{\mathrm{H}} 0.66(\mathrm{~s}, \mathrm{H}-18)$, 0.85 (s, H-19), 1.14 (d, $J=6.7 \mathrm{~Hz}, \mathrm{H}-21)$ and 1.07 (d, $J=6.8 \mathrm{~Hz}, \mathrm{H}-27)$ along with an olefinic proton $5.29(\mathrm{~d}, J=5.3 \mathrm{~Hz}, \mathrm{H}-11)$ and two anomeric protons at $\delta_{\mathrm{H}} 4.88(\mathrm{~d}, J=7.8 \mathrm{~Hz}, \mathrm{Gal}-\mathrm{H} 1)$ and $5.33(\mathrm{~d}, J$ $=7.8 \mathrm{~Hz}$, Glc-H1) were observed in the ${ }^{1} \mathrm{H}-\mathrm{NMR}$ spectrum of $\mathbf{1}$. The ${ }^{13} \mathrm{C}-\mathrm{NMR}$ spectrum displayed 39 carbon signals, in which a double bond carbons at $\delta_{\mathrm{C}} 147.3$ (C-9), 115.3(C-11), and two carbonyl carbon at $\delta_{\mathrm{C}} 217.1(\mathrm{C}-16)$ and $213.1(\mathrm{C}-22)$ and two oxygen-carbon signals at $\delta_{\mathrm{C}} 76.7(\mathrm{C}-3)$ and 67.3 (C-26) were observed. These data compared with the literature [8] supported the 
Two new cholestanol glycosides

$5 \alpha$-cholest-9(11)-ene-3 $\beta, 26$-dihydroxy-16, 22-dione aglycone of $\mathbf{1}$. This inference was deduced from 2D-NMR data analysis including HSQC, HMBC, NEOSY and ${ }^{1} \mathrm{H}-{ }^{1} \mathrm{H}$ COSY experiments (Figure 1). Detailed considering the ${ }^{1} \mathrm{H}$ and ${ }^{13} \mathrm{C}-\mathrm{NMR}$ spectra showed a galactose moiety with anomeric proton at $\delta_{\mathrm{H}} 4.88$ and carbon signals $(102.4,79.9,75.3,73.2,75.7,60.8)$ and a glucose with anomeric proton at $\delta_{\mathrm{H}} 5.33$ and carbon signals $(106.9,75.0,78.5,72.1,78.3,62.9)$ in $\mathbf{1}$, respectively [3]. The sugar sequence and its linkage site to the aglycone moiety were determined from the HMBC spectra. HMBC correlations observed between Gal-H1 $\left(\delta_{\mathrm{H}} 4.88\right)$ and C-3 $\left(\delta_{\mathrm{C}} 76.7\right)$, and between Glc-H1 $\left(\delta_{\mathrm{H}}\right.$ $5.33)$ and Gal-C2 $\left(\delta_{\mathrm{C}} 79.9\right)$, which disclosed that the D-galactose unit was linked at C-3 of aglycone, the D-glucose unit was linked at C-2 of the D-galactose. Acid hydrolysis of $\mathbf{1}$ resulted in the products of D-galactose and D-glucose which were confirmed by their optical rotation data $\left(\mathrm{Gal}:[\alpha]_{D}^{20}+29.0^{\circ}\right.$, $\mathrm{MeOH}$ and Glc: $\left.[\alpha]_{D}^{20}+48.8^{\circ}, \mathrm{MeOH}\right)$ and $R_{f}$ values $\left(\mathrm{BuOH}-\mathrm{AcOH}-\mathrm{H}_{2} \mathrm{O}, 4: 1: 5\right.$ upper layer, Gal: 0.39 and Glc: 0.36) with the authentic sugar samples [9]. Coupling constants of the anomeric proton signals ( $7.8 \mathrm{~Hz}$ each) suggested the $\beta$-configurations for the D-galactose and D-glucose, respectively [12-13]. Then the structure of 1 was deduced as $5 \alpha$-cholest-9(11)-ene-3 $\beta$, 26-dihydroxy-16, 22-dione 3- $O$ - $\beta$-D-glucopyranosyl-( $1 \rightarrow 2)-\beta$-D-galactopyranoside (1, Figure 1$)$.

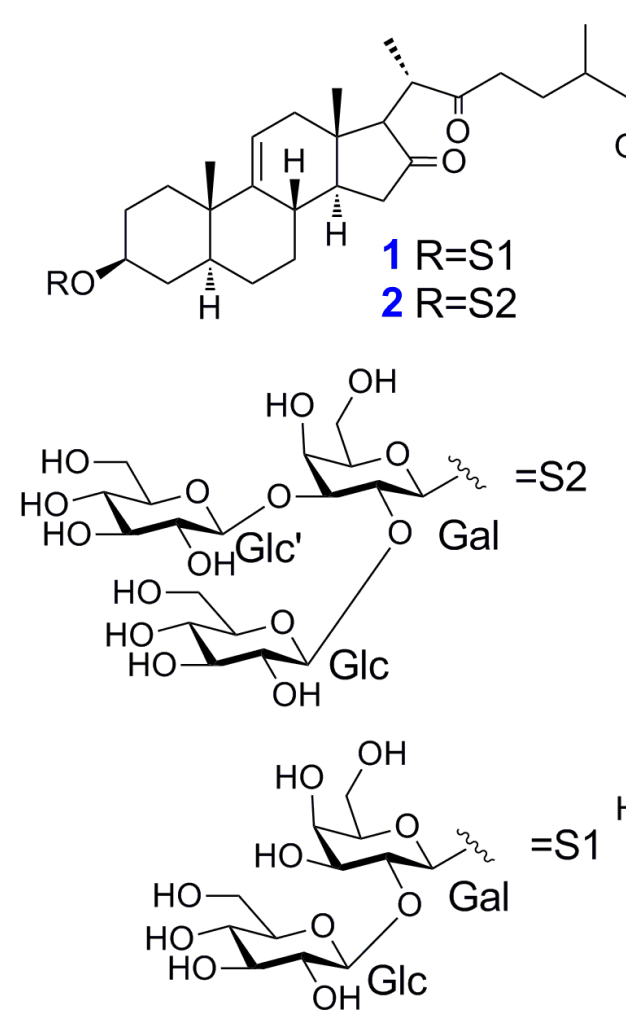

: ${ }^{1} \mathrm{H}-{ }^{1} \mathrm{H}$ COSY

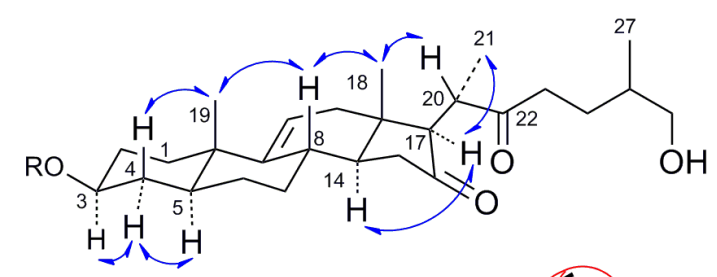

1 and 2

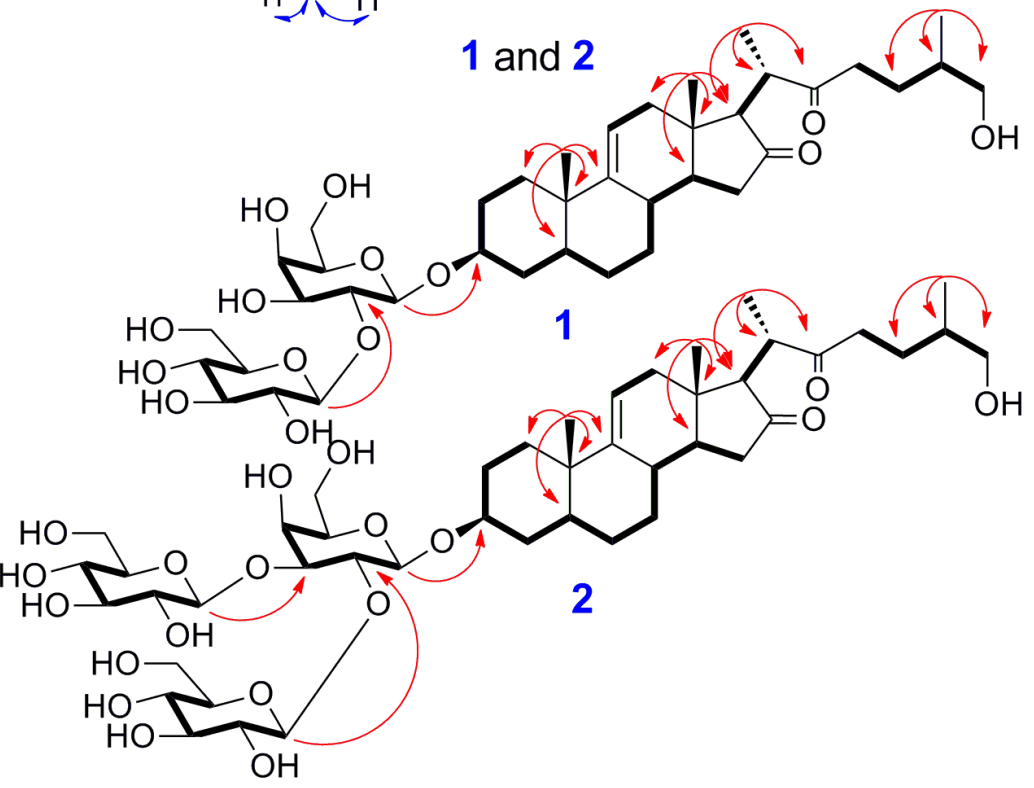

H $:$ HMBC

$\overbrace{\mathrm{H}}^{\mathrm{H}}:$ NOESY

Figure 1. Structures and key ${ }^{1} \mathrm{H}-{ }^{1} \mathrm{H}$ COSY, HMBC and NOESY correlations of $\mathbf{1}$ and $\mathbf{2}$ 
Table 1. ${ }^{1} \mathrm{H}$ and ${ }^{13} \mathrm{C}-\mathrm{NMR}$ data ${ }^{\mathrm{a}}(\delta$ in ppm, $J$ in $\mathrm{Hz})$ of $\mathbf{1}$ and $\mathbf{2}$

\begin{tabular}{|c|c|c|c|c|c|c|c|c|c|}
\hline \multirow{2}{*}{ NO } & \multicolumn{2}{|l|}{1} & \multicolumn{2}{|l|}{2} & \multirow{2}{*}{ NO } & \multicolumn{4}{|c|}{2} \\
\hline & $\delta_{\mathrm{H}}$ & $\delta_{\mathrm{C}}$ & $\delta_{\mathrm{H}}$ & $\delta_{\mathrm{C}}$ & & $\delta_{\mathrm{H}}$ & $\delta_{\mathrm{C}}$ & $\delta_{\mathrm{H}}$ & $\delta_{\mathrm{C}}$ \\
\hline \multirow{2}{*}{1} & $1.31 \mathrm{~m}$ & \multirow{2}{*}{35.4} & $1.31 \mathrm{~m}$ & \multirow{2}{*}{35.4} & Gal-1 & $4.88, \mathrm{~d}(7.8)$ & 102.4 & $4.91, \mathrm{~d}(7.8)$ & 102.3 \\
\hline & $1.63 \mathrm{~m}$ & & $1.62 \mathrm{~m}$ & & 2 & $4.73 \mathrm{~m}$ & 79.9 & $4.58 \mathrm{ov}$ & 80.8 \\
\hline \multirow{2}{*}{2} & $1.73 \mathrm{~m}$ & \multirow{2}{*}{29.8} & $1.72 \mathrm{~m}$ & \multirow{2}{*}{29.8} & 3 & $4.11 \mathrm{ov}$ & 75.3 & $4.13 \mathrm{ov}$ & 85.9 \\
\hline & $2.19 \mathrm{~m}$ & & $2.17 \mathrm{~m}$ & & 4 & $4.42, \mathrm{~d}(9.2)$ & 73.2 & $4.50, \mathrm{~d}(9.2)$ & 73.1 \\
\hline 3 & $3.93 \mathrm{~m}$ & 76.7 & $4.03 \mathrm{~m}$ & 76.5 & 5 & $4.28 \mathrm{ov}$ & 75.7 & $3.97 \mathrm{ov}$ & 77.4 \\
\hline \multirow{2}{*}{4} & $1.77 \mathrm{~m}$ & \multirow{2}{*}{38.0} & $1.74 \mathrm{~m}$ & \multirow{2}{*}{38.0} & \multirow[t]{2}{*}{6} & $4.31 \mathrm{ov}$ & \multirow[t]{2}{*}{60.8} & $4.29 \mathrm{ov}$ & \multirow[t]{2}{*}{60.3} \\
\hline & $2.22 \mathrm{~m}$ & & $2.23 \mathrm{~m}$ & & & $4.78 \mathrm{~m}$ & & $4.79 \mathrm{~m}$ & \\
\hline 5 & $1.08 \mathrm{ov}$ & 42.8 & $1.06 \mathrm{ov}$ & 42.8 & Glc-1 & $5.33, \mathrm{~d}(7.8)$ & 106.9 & $5.16 \mathrm{ov}$ & 105.0 \\
\hline \multirow{2}{*}{6} & $1.21 \mathrm{~m}$ & \multirow{2}{*}{28.3} & $1.22 \mathrm{~m}$ & \multirow{2}{*}{28.3} & 2 & $4.09 \mathrm{ov}$ & 75.0 & $4.08 \mathrm{ov}$ & 75.4 \\
\hline & $1.25 \mathrm{~m}$ & & $1.24 \mathrm{~m}$ & & 3 & $4.25 \mathrm{ov}$ & 78.5 & $4.26 \mathrm{ov}$ & 78.7 \\
\hline \multirow{2}{*}{7} & $0.97 \mathrm{~m}$ & \multirow{2}{*}{33.0} & $0.96 \mathrm{~m}$ & \multirow{2}{*}{33.0} & 4 & $4.07 \mathrm{ov}$ & 72.1 & $4.24 \mathrm{ov}$ & 71.6 \\
\hline & $1.65 \mathrm{~m}$ & & $1.64 \mathrm{~m}$ & & 5 & $4.05 \mathrm{ov}$ & 78.3 & $4.07 \mathrm{ov}$ & 76.5 \\
\hline 8 & $1.98 \mathrm{~m}$ & 34.7 & $1.99 \mathrm{~m}$ & 34.7 & 6 & $4.22 \mathrm{ov}$ & & $4.38, \mathrm{~d}(10.8)$ & \\
\hline 9 & - & 147.3 & - & 147.3 & 0 & $4.64, \mathrm{~d}(10.8)$ & 02.9 & $4.59 \mathrm{ov}$ & 01.0 \\
\hline 10 & - & 38.0 & - & 38.0 & Glc-1' & & & $5.23, \mathrm{~d}(7.8)$ & 106.7 \\
\hline 11 & $5.29, \mathrm{~d}(5.3)$ & 115.3 & $5.28, \mathrm{~d}(5.3)$ & 115.2 & 2 & & & $4.09 \mathrm{ov}$ & 75.0 \\
\hline \multirow{2}{*}{12} & $1.63 \mathrm{ov}$ & \multirow{2}{*}{35.3} & $1.63 \mathrm{ov}$ & 353 & 3 & & & $3.96 \mathrm{ov}$ & 78.2 \\
\hline & $1.88 \mathrm{ov}$ & & $1.88 \mathrm{ov}$ & 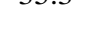 & 4 & & & $4.23 \mathrm{ov}$ & 70.1 \\
\hline 13 & - & 39.6 & - & 39.6 & 5 & & & $4.12 \mathrm{ov}$ & 78.0 \\
\hline 14 & $1.61 \mathrm{ov}$ & 47.8 & $1.61 \mathrm{ov}$ & 47.8 & 6 & & & $4.11 \mathrm{ov}$ & 630 \\
\hline 15 & $2.91, \mathrm{dd}(11.2,8.9)$ & 403 & $2.92, \mathrm{dd}(11.2,8.9)$ & 403 & & & & $4.65 \mathrm{ov}$ & 0.0 \\
\hline & $2.98, \mathrm{dd}(11.2,8.9)$ & & 2.96, dd $(11.2,8.9)$ & & & & & & \\
\hline 16 & - & 217.1 & - & 217.2 & & & & & \\
\hline 17 & $2.83, \mathrm{~d}(10.9)$ & 65.8 & $2.83, \mathrm{~d}(10.9)$ & 65.8 & & & & & \\
\hline 18 & $0.66 \mathrm{~s}$ & 12.3 & $0.66 \mathrm{~s}$ & 12.4 & & & & & \\
\hline 19 & $0.85 \mathrm{~s}$ & 17.8 & $0.84 \mathrm{~s}$ & 17.8 & & & & & \\
\hline 20 & $2.78, \mathrm{dd}(10.9,6.7)$ & 43.3 & $2.78, \mathrm{dd}(10.9,6.7)$ & 43.3 & & & & & \\
\hline 21 & $1.14, \mathrm{~d}(6.7)$ & 15.3 & $1.14, \mathrm{~d}(6.7)$ & 15.3 & & & & & \\
\hline 22 & - & 213.1 & - & 213.1 & & & & & \\
\hline 23 & $2.11 \mathrm{~m}$ & 401 & $2.10 \mathrm{~m}$ & 401 & & & & & \\
\hline & $2.14 \mathrm{~m}$ & & $2.14 \mathrm{~m}$ & & & & & & \\
\hline 24 & $1.77 \mathrm{~m}$ & 275 & $1.77 \mathrm{~m}$ & 275 & & & & & \\
\hline 27 & $2.22 \mathrm{~m}$ & 21.0 & $2.22 \mathrm{~m}$ & 21.0 & & & & & \\
\hline 25 & $1.81 \mathrm{~m}$ & 35.9 & $1.81 \mathrm{~m}$ & 35.9 & & & & & \\
\hline 26 & $3.74, \mathrm{~d}(10.5)$ & 673 & $3.74, \mathrm{~d}(10.5)$ & 73 & & & & & \\
\hline 20 & 3.81 , dd $(10.5,6.8)$ & 07.0 & $3.82, \mathrm{dd}(10.5,6.8)$ & (1.0. & & & & & \\
\hline 27 & $1.07, \mathrm{~d}(6.8)$ & 17.1 & $1.08, \mathrm{~d}(6.8)$ & 17.1 & & & & & \\
\hline
\end{tabular}

${ }^{\mathrm{a}}{ }^{1} \mathrm{H}-\mathrm{NMR}$ and ${ }^{13} \mathrm{C}-\mathrm{NMR}$ were measured at $400 \mathrm{MHz}$ and $100 \mathrm{MHz}$ in pyridine- $d_{5}$, and the assignments were based on the HSQC, HMBC, NOESY and ${ }^{1} \mathrm{H}-{ }^{1} \mathrm{H}$ COSY experiments; ov: overlap signals. 
Compound 2, was obtained as white amorphous powder, with $[\alpha]_{D}^{20}-20.0^{\circ}(c 0.10, \mathrm{MeOH})$, which has the molecular formula of $\mathrm{C}_{45} \mathrm{H}_{72} \mathrm{O}_{19}$ supporting by the HR-ESI-MS positive molecular ion peak at $m / z 939.4532[\mathrm{M}+\mathrm{Na}]^{+}\left(\right.$calcd for $939.4565[\mathrm{M}+\mathrm{Na}]^{+}$). When comparing the NMR data of 2 and 1, they showed almost the similar NMR spectroscopic features of the aglycone. Therefore, the aglycone of 2 was deduced as $5 \alpha$-cholest-9(11)-ene-3 $\beta, 26$-dihydroxy-16, 22-dione [8] which was further supported by 2D-NMR data analysis (Figure 1). The difference between $\mathbf{2}$ and $\mathbf{1}$ was the sugar moiety in 1 (3- $O-\beta$-D-glucopyranosyl-( $1 \rightarrow 2)-\beta$-D-galactopyranoside) which was replaced by 3 - $O$ - $\beta$-D-glucopyranosyl-( $1 \rightarrow 2)$-[ $\beta$-D-glucopyranosyl- $(1 \rightarrow 3)]-\beta$-D-galactopyranoside in $2[3,4]$. This inference was determined from the HMBC correlations from 4.91 (Gal-H1) to 76.5 (C-3), from $5.16(\mathrm{Glc}-\mathrm{H} 1)$ to 80.8 (Gal-C2) and from 5.23 (Glc'-H1) to 85.9 (Gal-H3). The $\beta$-configurations for the D-galactose and D-glucose in $\mathbf{2}$ were identified as the same method as $\mathbf{1}$. Compound $\mathbf{2}$ was thus deduced as $5 \alpha$-cholest-9(11)-ene-3 $\beta$, 26-dihydroxy-16, 22-dione 3-O- $\beta$-D-glucopyranosyl-( $1 \rightarrow 2)$ [ $\beta$-D-glucopyranosyl-( $(1 \rightarrow 3)]-\beta$-D-galactopyranoside $(2$, Figure 1$)$.

Steroidal glycosides, possessing various cytotoxic activities, have been isolated from the genus Smilacina [2, 4-8]. In this paper, the cytotoxic activity against human HepG2 tumor cells of compounds $\mathbf{1}$ and $\mathbf{2}$ were evaluated by the MTT method. The results showed that only compound $\mathbf{2}$ exhibited moderate effect with $\mathrm{IC}_{50}$ value of $59.32 \mu \mathrm{M}$.

\section{Acknowledgements}

This study was financially supported by the Key Laboratory Project of Shaanxi Education Department (Study on the antitumor pharmacodynamic substance basis of Smilacina henryi).

\section{Supporting Information}

Supporting information accompanies this paper on http://www.acgpubs.org/journal/ records-of-natural-products

\section{ORCID}

Xin Zhang: 0000-0003-0124-099X

Jing Sun: 0000-0002-8267-2067

Shuo Zhang: 0000-0001-9064-1722

Yafeng Yan: 0000-0002-7391-0166

Rongxin Zhang: 0000-0002-5222-911X

Xuanji Xue: 0000-0003-2487-9702

Zengjun Guo: 0000-0003-3266-6280

\section{References}

[1] X. M. Song and H. J. Liu (2011). Research and Application of "Qi-Medicines" in Taibai Mountains, People's Medical Publishing House, Beijing.

[2] X. Liu, H. Zhang, X. F. Niu, W. Xin and L. Qi (2012). Steroidal saponins from Smilacina japonica, Fitoterapia 83, 812-816. 
[3] J. Lin, G. Q. Wang, L. Bai and L. Z. Yu (2018). Steroidal components from rhizome of Smilacina henryi. Chin. Tradit. Herbal. Drugs. 49, 3987-3991.

[4] Y. W. Cui, X. J. Yang, D. D. Zhang, Y. Z. Li, L. Zhang, B. Song, Z. G. Yue, X. M. Song and H. F. Tang (2018). Steroidal constituents from roots and rhizomes of Smilacina japonica, Molecules 23, 798-806.

[5] S. L.Yang, X. K. Liu, H .Wu, H. Wang and C. Qing (2009). Steroidal saponins and cytoxicity of the wild edible vegetable—Smilacina atropurpurea, Steroids 74, 7-12.

[6] X. Zhang, Y. F. Su, L. Chen, X. Huang, S. L.Yan, X. Chai and X. M. Gao (2013). Steroidal saponins from the rhizomes of Smilacina henryi, Helv. Chim. Acta 96, 478-487.

[7] Y. Zhang, H. Z. Li, Y. J. Zhang, M. R. Jacob, S. I. Khan, X. C. Li and C. R.Yang (2006). Atropurosides A-G, new steroidal saponins from Smilacina atropurpurea. Steroids 71, 712-719.

[8] F. Qiao, J.Yang, J. Lin and S. Yao (2019). Four new steroidal components from Smilacina henryi and their cytotoxic activities, Phytochem. Lett. 29, 173-177.

[9] H. Zhang, Z. J. Guo, N. Wu, W. M. Xu, L. Han, N. Li and Y. X. Han (2012).Two novel naphthalene glucosides and an anthraquinone isolated from Rumex dentatus and their antiproliferation activities in four cell lines, Molecules 17, 843-850.

[10] S. K. Xu, A. X. Zou, Z. J. Guo and C. P. Wan (2017). Ethyl caffeate ameliorates collagen-induced arthritis by suppressing Th1 immune response, J. Immu. Res. 2017,1-11.

[11] J. Chai, X. M. Song, X. Wang, Q. B. Mei, Z. Li, J. C. Cui, Z. S. Tang and Z. G. Yue (2014). Two new compounds from the roots and rhizomes of Trillium tschonoskii, Phytochem. Lett. 10, 113-117.

[12] X. M. Song, D. D. Zhang, H. He, Y. Z. Li, X. J. Yang, C. Deng, Z. S. Tang, J. C. Cui and Z. G. Yue (2015). Steroidal glycosides from Reineckia carnea, Fitoterapia 105, 240-245.

[13] D. D. Zhang, W. Wang, Y. Z. Li, Z. Li, Y. Jiang, Z. S. Tang, X. M. Song and Z. G. Yue (2016). Two new pregnane glycosides from Reineckia carnea, Phytochem. Lett. 15, 142-146.

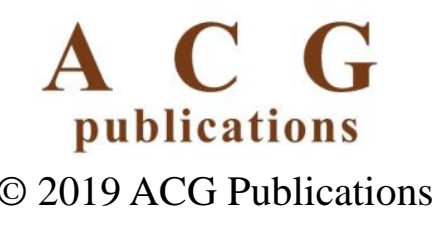

